\title{
Os destinos da Ilusão e a tênue fronteira entre o delírio e a dor ${ }^{161}$ Marilia Amaro da Silveira Modesto Santos 162
}

\begin{abstract}
Eu atravesso as coisas - e no meio da travessia não vejo! - só estava era entretido na ideia dos lugares de saída e de chegada. Assaz de o senhor sabe: a gente quer passar um rio a nado, e passa; mas vai dar na outra banda é num ponto muito mais embaixo, bem diverso do que em primeiro se pensou. Viver nem não é muito perigoso? ...O senhor já sabe: viver é etcétera...
\end{abstract}

O que há entre a ilusão e o delírio senão uma imensa dor?

O filme "A ilha do medo", se passa na década de 50, em um grande hospital psiquiátrico, situado em uma ilha, e inicia-se com o delegado federal Teddy Daniels e seu assistente que chegam lá com a missão de investigar o porquê do desaparecimento de uma interna.

No desenrolar da história, depois de algumas conversas com o corpo de funcionários do hospital, o investigador chega à conclusão de que a mulher desaparecida foi assassinada, o que o leva a intensificar obsessivamente a busca do assassino no hospital psiquiátrico - um monstro incendiário responsável pela morte da mulher dele e pelo fogo que, em seguida, é ateado na casa deles.

Do suspense ao drama que beira o terror, "A ilha do Medo" surpreende pelo clima de dúvida que paira em relação a quem é o doente mental, pois a tecedura vai se dando de tal forma que faz com que os espectadores indaguem quem era $o$ "louco": quem se apresentava como detetive ou o corpo de funcionários do hospital psiquiátrico?

São dúvidas que deixam o ouvinte à deriva da imaginação, que circunda entre o real e o fictício $\mathrm{O}$ enredo nos envolve de tal forma que nos faz sentir dentro do hospital psiquiátrico, no papel de espectadores/detetives, como um terceiro olhar em busca de desvendar o mistério que acaba se elucidando quando é revelado que o delegado é, na verdade, um dos internos do hospital. Trata-se de um veterano da segunda guerra, condecorado, e ex-delegado federal que acabou traumatizado após participar da libertação de um campo de concentração, desenvolvendo, no pós-guerra, propensão à violência sem manifestar remorsos

\footnotetext{
${ }^{161}$ Apresentado em Trabalhos livres no II Simpósio Bienal SBPSP "Fronteiras da Psicanálise: a clínica em movimento" no dia 28 de agosto de 2020.

${ }^{162}$ Membro Efetivo da Sociedade Brasileira de Psicanálise de São Paulo, Mestre em Psicologia Clínica pela Pontifícia Universidade Católica de São Paulo.
} 
pelos seus crimes, pois nega que eles ocorreram. Após deixar o exército, ele ingressa na carreira policial, e se torna um delegado de polícia. Ele é pai de três crianças com uma jovem depressiva que, em meio à sua insanidade, acaba matando os seus três filhos afogados em um lago. Quando o delegado chega a sua casa, após o trabalho, encontra a sua mulher, sentada à beira do lago, onde boiavam os corpos dos seus filhos e, em seu desespero, atira em sua mulher matando-a, e em seguida põe fogo na casa.

Impossibilitado de aceitar a penosa realidade, o delegado, em um processo de desintegração do self, acaba por desenvolver um delírio onipotente assumindo a identidade de um investigador que vai descobrir o assassino de uma indefesa enferma e salvar os demais internos do cruel matador. Ele tem o poder de descobrir a verdade e libertar os outros detentos da barbárie que ele acredita estar acontecendo no hospital.

No entanto, esse poderoso detetive encobre um outro nele: Um desesperançado monstro incendiário responsável pela morte da sua esposa após atear fogo em sua casa, que, por sua vez, esconde um sentimento de solidão radical de experiência agonística.

Freud, em seu trabalho "Lembranças encobridoras" (1898/1899) relata que se o indivíduo não tem condições interna de olhar a verdade consciente ou inconsciente, ela é substituída por mentira, autoengano ou alucinação.

M. Khan (1974) define os sintomas como auto tratamento - a maneira pela qual o sujeito procurou cuidar-se do impacto traumático da situação extrema, agonística, que ele teve de atravessar quando as necessidades do eu não foram consideradas no decorrer do longo período de vida.

Isto posto, e levando em conta que alguns delírios que surgem na fase adulta, possam ser resultados de falhas na passagem da ilusão para a apresentação da realidade, qual seria, então, a vereda que o psicanalista pode seguir com esses pacientes?

O psicanalista trabalha com a transferência da função primária, em meio a uma revivescência de aspectos infantis, vividos na dupla paciente/analista. Nesse caso, o paciente precisa que o analista esteja lá, presente. (Khan, 1974)

Roussillon (2019, p. 233) em "As funções do objeto e o meio maleável” propõe o conceito de partilha do afeto, isto é, o clínico deve intervir naquilo que 
o paciente vive naquele momento e, a adaptação à realidade deve ser feita sob medida.

Cita o autor:

... o clínico pode agir ali, onde o sujeito foi enxotado da condição humana. Pois o que caracteriza a expulsão para fora do espaço simbólico da condição humana, é precisamente, em primeiro lugar, a impressão que a experiência psíquica não é partilhável (p. 232bb).

Isso quer dizer que o analista precisa suportar a regressão até esse ponto, para que o paciente possa criar confiança no setting, acreditar que o analista seja capaz de sustentar essa volta, o retorno à dependência absoluta, o vazio de identidade; só assim, ele pode contribuir para a restauração de um self danificado e levar o paciente a viver o desdobramento do amor e do ódio. Nessa volta o paciente tem a chance de passar do delírio para a ilusão e, aos poucos, o tempo e o espaço, enfim, a realidade, possa ser introduzida, sem que seja sentida como invasora.

No início da vida o bebê pode sentir os momentos de solidão como devastadores, quando ele realmente está só (Green, 1988, p. 121). O que o faz suportar esses períodos sem entrar em estado de agonia é a capacidade de ilusão.

Explicando: Seguindo na esteira de Winnicott o mundo existe antes de o bebê nascer, mas ele não sabe disso e, portanto, acredita que o que ele encontra foi ele que criou.

Após as primeiras mamadas, o bebê já tem material para criar e por isso se torna capaz de alucinar o mamilo quando há o aumento da tensão instintual. Se a mãe estiver presente e se a resposta do objeto satisfizer a excitação, a alucinação se transforma em ilusão de autossatisfação, ou ilusão primária. Com o passar do tempo, o bebê - ajudado pela memória - passa a tolerar a ausência da mãe porque sabe que ela voltará.

Portanto, se a preocupação materna primária for decrescendo à medida que o bebê possa suportar, é desencadeada a destrutividade, a separação e o uso do objeto sendo, nesse momento, fundamental que o objeto sobreviva a “destruição”. Logo, tudo se dá a partir da alucinação do bebê que possui um poder mágico - mas, que só é possível se a mãe estiver lá na hora que ele precisar. 
Resumindo: $\mathrm{O}$ reconhecimento da realidade ocorre gradualmente $\mathrm{e}$ depende da conquista da ilusão que, por sua vez, depende da possibilidade de adaptação da mãe ao seu bebê.

No caso da ausência do objeto a excitação instintual e a alucinação vão ser tratadas pela evacuação e, eu acrescendo, à luz da minha clínica, a possível formação de delírios frente a situações dramáticas.

Retorno a cena do filme: em quem Teddy Daniels quis atirar? Em uma mãe ambiente deprimida causadora da morte psíquica dos seus filhos? Em uma realidade invasiva? Seria esse o caminho que ele encontrou na busca de uma companhia viva?

Durante as noites, o sono o agente federal era invadido por imagens mnêmicas que o atormentavam, como, por exemplo: crianças afogadas em um lago, um incêndio em um apartamento, pilhas de corpos subnutridos esperando para serem queimados ou enterrados.

Nesses momentos surge uma mulher que o aconselha insistentemente a sair daquela ilha - do sofrimento atroz? Seria essa imagem rasgos de esperança de uma boa mãe, capaz de tirá-lo do tormento?

Nessa busca...

No hospital psiquiátrico, enquanto investigador de um assassinato, em meio ao seu delírio, ele era alguém que edificava o seu lugar no mundo, conquistava a admiração e o amor do outro, o encontro com amor primário? (Ballint ,2014).

O filme termina sem deixar claro se ele, por efeito dos psicotrópicos, tinha alcançado o contato com a realidade, ou fingia concordar com os médicos para continuar à procura do assassino e salvar os internos... a ele mesmo?

Para os espectadores continuou a dúvida: quem era o louco?

Para o tenente: Se eu não for o louco eu não sou para o mundo, se eu for o investigador... sou?

...O senhor já sabe: viver é etcétera...

\section{Referências}

Ballint, M. Narcisismo rimário e amor primário in A falha básica: Aspectos terapêuticos da regressão, 2014, Zagodoni Editora Ltda. 
Freud, S. Lembranças encobridoras (1899) In S. Freud, Obras completas V. 5, Editora Imago Rio de Janeiro (1976).

Green, A. Encontro com grupos em Conferências Brasileiras - Metapsicologia dos limites (1990) Imago Editora, rio de Janeiro.

Khan, M. (1960) Regressão e integração no setting analítico. Ensaio Clínico sobre os aspectos transferenciais e contra-transferênciais desses fenômenos em Psicanálise: Teoria Técnica e Casos Clínicos (1974), Francisco Alves Editora S. A., Rio de Janeiro.

Roussillon, R. (20219 As funções do objeto (do clínico) e o Meio Maleável em Manual da prática clínica em psicologia,2019, Editora Edgard Bloucher Ltda, São Paulo.

Winnicott, D. W. O valor da ilusão e os estados transicionais em Natureza Humana (1971) Imago Editora, Rio de Janeiro. 